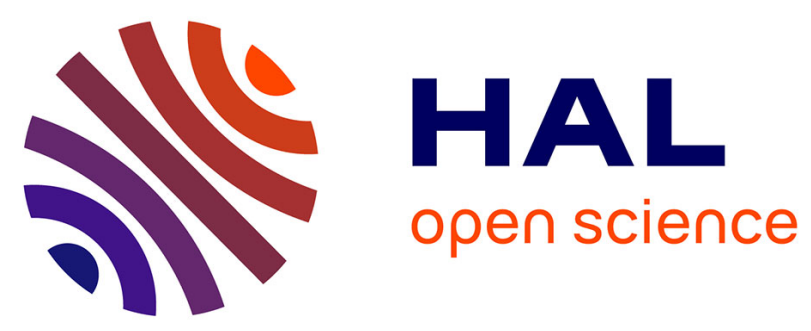

\title{
Time to rethink the management intensity in a Mediterranean oak woodland: the response of insectivorous birds and leaf-chewing defoliators as key groups in the forest ecosystem
}

Pedro Pereira, Carlos Godinho, Inês Roque, Ana Marques, Manuela Branco, João Eduardo Rabaça

\section{To cite this version:}

Pedro Pereira, Carlos Godinho, Inês Roque, Ana Marques, Manuela Branco, et al.. Time to rethink the management intensity in a Mediterranean oak woodland: the response of insectivorous birds and leaf-chewing defoliators as key groups in the forest ecosystem. Annals of Forest Science, 2012, pp.25-32. 10.1007/s13595-012-0227-y . hal-01098323

\section{HAL Id: hal-01098323 https://hal.science/hal-01098323}

Submitted on 12 Jan 2015

HAL is a multi-disciplinary open access archive for the deposit and dissemination of scientific research documents, whether they are published or not. The documents may come from teaching and research institutions in France or abroad, or from public or private research centers.
L'archive ouverte pluridisciplinaire HAL, est destinée au dépôt et à la diffusion de documents scientifiques de niveau recherche, publiés ou non, émanant des établissements d'enseignement et de recherche français ou étrangers, des laboratoires publics ou privés. 


\title{
Time to rethink the management intensity in a Mediterranean oak woodland: the response of insectivorous birds and leaf-chewing defoliators as key groups in the forest ecosystem
}

\author{
Pedro Pereira • Carlos Godinho • Inês Roque • \\ Ana Marques • Manuela Branco • \\ João Eduardo Rabaça
}

Received: 26 March 2012 / Accepted: 9 July 2012 /Published online: 1 August 2012

(C) INRA / Springer-Verlag France 2012

\begin{abstract}
- Context The Iberian cork oak Quercus suber montados are dynamic agro-silvo-pastoral systems, contrasting with the abandonment trend of other Mediterranean forested areas.

- Aims We aimed to identify the effect of management type and vegetation features on breeding insectivorous birds and leaf-chewing defoliator insects.

- Methods In central Portugal, we selected two groups of 20 sites: dense montados (DM, high cover of cork oaks and low cattle impact) and sparse montados (SM, low cover of oaks and high cattle impact). We collected variables associated with vegetation features, bird community and chewing defoliators. - Results The two systems differed significantly in oak trunk diameter, oak and shrub cover, tree and shrub diversity. Ground bird densities were higher in SM with fragmented shrub cover. In DM, higher woody vegetation cover and diversity can promote shrub birds and leaf warblers.
\end{abstract}

Handling Editor: Francois Lieutier

Contribution of the co-authors Pedro Pereira designed the experiment, conducted field work, data analysis and manuscript writing. Carlos Godinho designed the experiment, conducted field work and manuscript reviewing. Inês Roque designed the experiment and manuscript reviewing. Ana Marques reviewed the manuscript. Manuela Branco designed the experiment and reviewed the manuscript. João Eduardo Rabaça designed the experiment, coordinated the research project and reviewed the manuscript.

P. Pereira $(\bowtie) \cdot$ C. Godinho - I. Roque · A. Marques · J. E. Rabaça LabOr-Laboratório de Ornitologia, Instituto de Ciências Agrárias e Ambientais Mediterrânicas, University of Évora,

7002-544 Évora, Portugal

e-mail: ppereira@uevora.pt

M. Branco

Departamento de Engenharia Florestal, Instituto Superior

Agronomia, Technical University of Lisbon,

Tapada da Ajuda,

1349-017 Lisbon, Portugal
Oak defoliation was mainly attributed to the sawfly Periclista andrei. Sawfly defoliation was significantly higher in SM and negatively correlated with shrub cover.

- Conclusions Our results highlight (1) the relevance of management activities conducted at the shrubby layer, (2) the need of an increase in tree diversity and density and (3) the maintenance of a mosaic landscape in order to improve the bird community richness and reduce the defoliation impact in montado system.

Keywords Birds $\cdot$ Defoliators $\cdot$ Mediterranean forest . Management $\cdot$ Montados $\cdot$ Cork oak

\section{Introduction}

The Portuguese montados and Spanish dehesas are agro-silvopastoral systems highly sustainable and unique at European scale, where livestock raising, cork (from cork oak Quercus suber), timber (from holm oak Q. rotundifolia), cereal crops and game can be promoted, often simultaneously (e.g. Bugalho et al. 2009; Pinto-Correia and Mascarenhas 1999; ScarasciaMugnozza et al. 2000). These forested areas, composed mainly of evergreen oaks, support higher species richness than other Mediterranean forests, namely in terms of plants, arthropod and bird communities (e.g. Barriga et al. 2010; Marañon 1986; Martins da Silva et al. 2008; Tellería 2001). The main reason for holding such important biodiversity is related to the spatial heterogeneity of the ecosystem and the presence of an ecotone between open and forest habitats (Tellería 2001).

Scarascia-Mugnozza et al. (2000) highlighted the need of knowledge on land cover management and biological diversity, in conservation and valuation of Mediterranean forests. Although several countries from Southern Europe are 
experiencing land abandonment of their forests, a different trend is detected in cork oak montados (see Pinto-Correia and Mascarenhas 1999). As agro-silvo-pastoral systems, montados have diverse and more frequent management activities through the year rather than purely wood production systems (e.g. pine Pinus spp. or eucalyptus Eucalyptus spp.; see for instance Barriga et al. 2010; Martins da Silva et al. 2008; ScarasciaMugnozza et al. 2000). Therefore, the effects of their multifunctional uses in their biodiversity must be better understood. Since Iberian oak habitats are managed in different system types (e.g. with different densities and diversities of trees and shrubs), the intensity of human activities has been the target of some studies (e.g. Bugalho et al. 2009, 2011; Herrera 1984; Leiva and Fernández-Alés 2005). Accordingly, intense livestock grazing impact is known to negatively affect oak and shrub development, and consequently the composition of soil invertebrate community (Bugalho et al. 2009, 2011). However, insects which feed on fallen acorns are not dependent on habitat exploitation based on pruning and grazing effects, presenting similar attack rates despite the intensity of system exploitation (Leiva and Fernández-Alés 2005). On the other hand, the diversity of fleshy fruit shrubs is known to affect the composition of bird communities, at least out of their breeding season (Herrera 1984). As a consequence, the promotion of a particular type of montado can have different effects in densities and composition of their wildlife communities. Few studies addressed the effects of oak woodland management and vegetation features on two key community groups in their ecosystem equilibrium: (1) insectivorous birds as secondary consumers, the dominant trophic group in bird communities of evergreen oak habitats (Camprodon and Brotons 2006; Godinho and Rabaça 2011; Pulido and Díaz 1992) and (2) defoliator insects as primary consumers, which determine the success of bottom-up and top-down effects among trophic levels, as plants productivity and breeding success of predatory birds (Murakami and Nakano 2000; Rubtsov 1996; Southwood et al. 2004). Defoliators have particular ecological interest since larval instars of moths (Lepidoptera) and sawflies (Hymenoptera, Tenthredinidae) are considered pests with annual outbreaks in montados (Ferreira and Ferreira 1991), being indicators of erroneous silvicultural practices (e.g. Jactel and Brockerho 2007). Moreover, great caterpillar defoliation rates in cork oaks are known to affect cork production, jeopardizing its economical value (Branco and Ramos 2009). However, sawflies larvae are generally misidentified as moth caterpillars and consequently broadly ignored in other studies (Smith 2006).

Since intensive management practices in European farmlands are known to reduce the food and habitat availability for bird populations and increase the system suitability to insect pests (Bengtsson et al. 2005; BirdLife International 2004), we expect similar trends with montados intensification. Accordingly, we hypothesize that in montados with high management intensity the bird density is lower and the oak defoliation damage by leafchewing insects is higher when compared with montados with reduced management activity. Consequently, taking into account their relevance to the ecological functions and ecosystem services, we aimed to identify the effect of management type and vegetation features on the density and composition of insectivorous bird guilds and on intensity of oak defoliation damage.

\section{Methods}

\subsection{Study area}

Field work was conducted in central Portugal $\left(8^{\circ} 48^{\prime} \mathrm{W}\right.$ and $38^{\circ} 50^{\prime} \mathrm{N}$; Fig. 1). The study area is located in Companhia das Lezírias S.A., a public ownership farm where rice, wine, pine wood, cork and livestock are produced. The slope is soft and altitude ranges between $15 \mathrm{~m}$ and 50 ma.s.l. Climate is typically Mediterranean with hot and dry summers and moderate rainy winters: mean temperature ranges from $9{ }^{\circ} \mathrm{C}$ in January to $22{ }^{\circ} \mathrm{C}$ in July and the mean annual rainfall is $644 \mathrm{~mm}$ (Costa et al. 2008). The woodland area $(8,000 \mathrm{ha})$ are dominated by montados of cork oak sorted in plots with different tree densities and cattle grazing intensities. Cork is harvested from oak trunks each 9 years. Maritime pine Pinus pinaster and stone pine Pinus pinea occur mixed with oaks (representing always $\leq 10 \%$ of trees) or planted in small stands ( $\leq 350 \mathrm{ha}$ ).

\subsection{Sampling sites}

A sampling site was comprised of a circular area with limited distance (100 $\mathrm{m}$ radius, adapted to $3 \mathrm{ha}$ ) located at

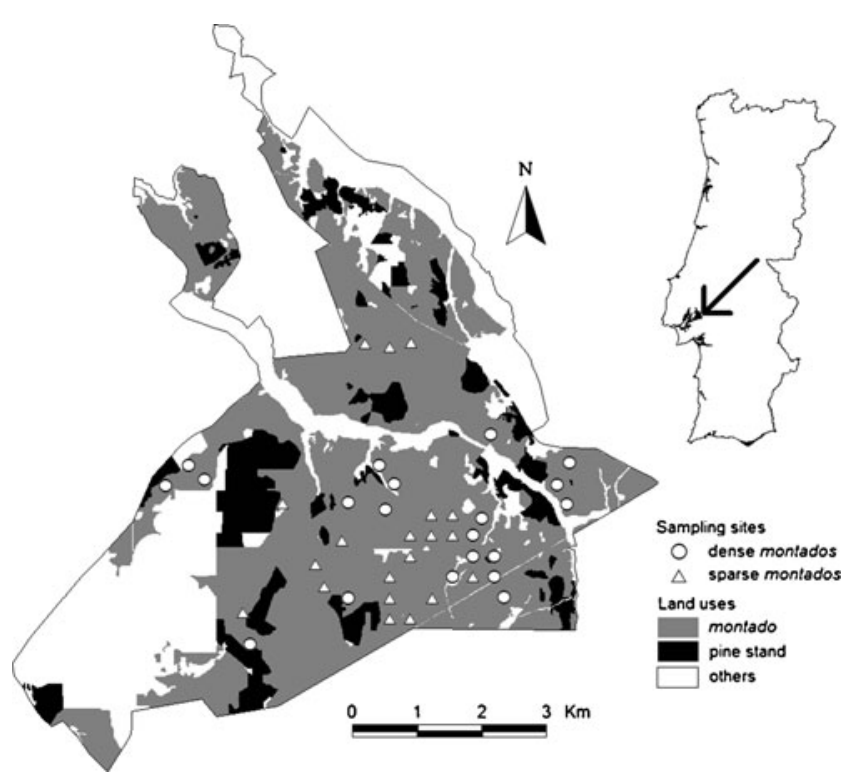

Fig. 1 Location of study area, main land uses and sampling sites 
least $500 \mathrm{~m}$ away from the others. Forty sites were selected according two types of the montado management system. These two types are representative of the current trends of exploitation observed in Iberian evergreen oak woodlands (Bugalho et al. 2009; Pinto-Correia and Mascarenhas 1999; Smit et al. 2009): (a) sites with high cover of cork oak (6090 trees/ha) with 20-40 years old and low cattle density $(\leq 0.4$ heads/ha), hereafter called dense montados (DM; $n=$ 20); (b) sites with higher intensity of human activity, with reduced oak cover (30-50 trees/ha) with 30-70 years old and higher cattle density ( $0.6-1.3$ heads/ha), hereafter called sparse montados (SM; $n=20)$. The current status of both systems has resulted from the management activities conducted in the last two decades and also soil type constraints: DM dominate in arenosols and regosols whereas SM in gleysols and luvisols (see for instance Costa et al. 2008). Vegetation description, bird surveys and visual assessment of defoliator insect damage were conducted in all sites. Study was performed between late May and early June 2010 in order to include the peaks of bird breeding season and defoliation activity of insect larvae.

\subsection{Vegetation features}

In each site, vegetation traits were sampled in two strata: trees and understory, four and two variables, respectively. We randomly selected five oaks at least $10 \mathrm{~m}$ away from each other, avoiding trees with adjoined crowns. This number can be considered representative due to the homogeneity of tree age per site. For each oak, we measured the trunk diameter at breast height $(\mathrm{DBH} ; \mathrm{cm})$ and estimated the leaf density in one square meter of crown, in both north and south sides of the tree (foliage cover; expressed in percentage \%). The average values of sampled oaks by each site were obtained for statistical purposes. For the whole site area, the vegetation cover was visually estimated as the percentage of ground covered with shrub vegetation (shrubs cover; \%) and percentage of horizontal projection of tree crown area (oak cover; \%). We evaluated the woody vegetation diversity at each layer using the Shannon Diversity Index $\left(\mathrm{H}^{\prime}\right)$, take into account the percentage of horizontal projection of crowns of each tree species (tree diversity; $\mathrm{H}^{\prime}$ ) and the percentage of land covered by each shrub genus (shrub diversity; $\mathrm{H}^{\prime}$ ).

\subsection{Insectivorous birds}

In the centre of each sampling site, a point count census of 10 min was conducted (e.g. Bibby et al. 2000) by two experienced observers, with similar identification skills and distance estimation training, recording all seen and heard individuals. Bird surveys were carried once in spring, when territorial males actively defend their territories and exhibit a reduced mobility imposed by breeding constrains. Therefore, we considered $500 \mathrm{~m}$ as an enough distance between adjacent sites in order to avoid double counting. Surveys were conducted between 6:00 a.m. and 11:00 a.m., when birds are more active, avoiding days with adverse weather conditions such as moderate rain or strong wind.

We calculated the density of each bird species using only the males that were defending their territories during the census period (e.g. Bibby et al. 2000). Thereafter we expressed bird density in number of pairs per site ( $3 \mathrm{ha})$. We excluded from data treatment communal birds (e.g. spotless starling Sturnus unicolor), non-insectivorous species (e.g. goldfinch Carduelis carduelis), aerial-feeding birds (e.g. barn swallow Hirundo rustica) and omnivorous birds even during the breeding season (e.g. blackbird Turdus merula). The densities of birds were grouped into six ecological guilds based on their nesting and foraging substrates, adapted from Snow and Perrins (1998; see Table 1).

\subsection{Leaf-chewing defoliators}

Since we aimed to relate the management intensity with defoliator activity, we sampled their defoliation damage instead larvae abundance. Visual assessment of defoliation damage was carried out once in each site in late May 2010. Field work was conducted in three consecutive days in order to exclude any time effect among sites related with the metamorphosis development of defoliators (see Murakami and Nakano 2000; Sanz 2001; Southwood et al. 2004). The defoliation impact was sampled by estimating the proportion of leafs damaged in one square meter of crown, which is an indicative measure of larvae abundance (Sanz 2001). Observations were conducted in the same five oaks where crown density was estimated. Taxonomic identification was based on the shape of leaf damage: chew inward from the leaf edge for Lepidoptera and elliptical holes on blade for sawflies Periclista andrei (Hymenoptera, Tenthredinidae; Ferreira and Ferreira 1991). With preliminary works, using $12 \mathrm{~W}$ violet light trapping and visual observations, we identified the following main families of chewing moths as present in the study area: Arctiidae, Geometridae, Lymantriidae, Noctuidae, Notodontidae, Oecophoridae, Pyralidae, Tortricidae and Yponomeutidae. Since visual assessment was conducted for chewing defoliation estimation only, less abundant leaf dwelling insects such as leaf miners (mostly Gracillaridae, Lepidoptera) and skeletonizers (some Curculionidae and Chrysomelidae, Coleoptera) were not take into account in this study.

\subsection{Data analysis}

In order to evaluate the effect of both management types of montado and vegetation features in the communities of birds and defoliators, we performed several statistical analyses using SPSS 16.0 for Windows (SPSS 2007). The effect of 
Table 1 Bird species grouped in different ecological guilds, according to their nesting and foraging substrates

\begin{tabular}{|c|c|c|c|}
\hline Guild & Nesting substrate & Foraging substrate & Species \\
\hline Finches & Canopy & Canopy or ground & Chaffinch (Fringilla coelebs) \\
\hline $\begin{array}{l}\text { Climbing } \\
\text { birds }\end{array}$ & Tree hole & Mostly on bark & $\begin{array}{l}\text { Great spotted woodpecker (Dendrocopos major), short-toed } \\
\text { treecreeper (Certhia brachydactyla), nuthatch (Sitta europaea) }\end{array}$ \\
\hline Tits & Tree hole & Canopy, bark or ground & Blue tit (Cyanistes caeruleus), great tit (Parus major) \\
\hline Ground birds & Ground & Ground & $\begin{array}{l}\text { Woodlark (Lullula arborea), stonechat Saxicola torquata), fan-tailed warbler } \\
\text { Cisticola juncidis), corn bunting Emberiza calandra), cirl bunting Emberiza cirlus) }\end{array}$ \\
\hline Shrub birds & On or near shrubs & On or near shrubs & $\begin{array}{l}\text { Wren (Troglodytes troglodytes), nightingale (Luscinia megarhynchos), } \\
\text { Sardinian warbler (Sylvia melanocephala) }\end{array}$ \\
\hline Leaf warblers & Shrubs or trees & Shrubs or trees & $\begin{array}{l}\text { Melodious warbler (Hippolais polyglotta), Bonelli's warbler (Phylloscopus } \\
\text { bonelli) }\end{array}$ \\
\hline
\end{tabular}

management system on vegetation features, densities of each bird guilds and leaf-chewing defoliators was obtained by oneway ANOVA. Relations between bird densities and vegetation variables were obtained by the computation of Spearman's rank correlations. Identical procedure was conducted for defoliator and vegetation relationships. Correlations were considered significant at a 0.05 probability level.

\section{Results}

3.1 Relationships between management type and vegetation features

From woody vegetation surveys, 10 tree species and 11 shrub genera were indentified: cork oak and maritime pine were the commonest tree species, while rock roses Cistus ssp., gorses Ulex spp. and daphne Daphne gnidium were the most common shrubs (Table 2). Apart from foliage cover, vegetation features showed significant differences between the two studied management systems (Table 3). In general, SM was characterized by the presence of larger oaks. Comparatively, woody vegetation cover and diversity were higher in DM.

\subsection{Effects of management type and vegetation features} on insectivorous birds

The average bird species richness per site was $8.5 \pm 1.9$ and $7.2 \pm 1.6$ at DM and SM, respectively. The most abundant bird guilds ( $>2.0$ pairs $/ 3$ ha) were finches and ground birds at SM and shrub-birds at DM. Some guilds showed significant differences in their densities depending on the management systems: ground birds were more common in SM, but shrub birds and leaf warblers showed lower densities in this system (Table 4). These three bird guilds, together with tits showed significant correlation coefficients $(p \leq 0.05)$ with several vegetation features. The unique significant correlation with tree strata traits was obtained for tits with oak foliage cover $\left(r_{\mathrm{s}}=-0.37, p=0.05\right)$. Shrub cover had a negative effect on ground birds $\left(r_{\mathrm{s}}=-0.27, p=0.04\right)$, but showed the inverse relation with shrub birds and leaf warblers $\left(r_{\mathrm{s}}=0.67, p<0.01\right.$ and $r_{\mathrm{s}}=0.63, p<0.01$, respectively). When we considered the vegetation diversity, the increase of tree and shrub diversity presented positive effects on two bird guild densities: shrub birds and leaf warblers with shrub diversity $\left(r_{\mathrm{s}}=0.69, p<0.01\right.$ and $r_{\mathrm{s}}=0.54, p<0.01$, respectively); shrub birds and leaf warblers with tree diversity ( $r_{\mathrm{s}}=0.46, p<0.01$ and $r_{\mathrm{s}}=0.61, p<0.01$, respectively).

Table 2 Tree species and shrub genera, land cover average and standard deviation according the two management types: dense montados (DM) and sparse montados (SM)

\begin{tabular}{llrl}
\hline & Species/genera & DM & SM \\
\hline Trees & Kermes oak Quercus coccifera & $1 \pm 0$ & $0 \pm 0$ \\
& Grey willow Salix atrocinerea & $2 \pm 1$ & $0 \pm 0$ \\
& Maritime pine Pinus pinaster & $7 \pm 1$ & $1 \pm 0$ \\
Strawberry tree Arbutus unedo & $2 \pm 0$ & $0 \pm 0$ \\
Iberian pear Pyrus bourgaeana & $1 \pm 0$ & $0 \pm 0$ \\
Other trees: stone pine Pinus pinea, & $1 \pm 0$ & $0 \pm 0$ \\
$\quad$ narrow-leafed ash Fraxinus angustifolia, & & \\
$\quad$ olive tree Olea europaea var. sylvestris, & & \\
$\quad$ hawthron Crataegus monogyna & $13 \pm 3$ & $0 \pm 0$ \\
Gorses Ulex spp. & $18 \pm 3$ & $9 \pm 2$ \\
Rock roses Cistus spp. & $6 \pm 1$ & $3 \pm 1$ \\
Halimium spp. & $8 \pm 2$ & $1 \pm 0$ \\
Daphne Daphne gnidium & $3 \pm 1$ & $3 \pm 1$ \\
Heaths Erica spp. & $6 \pm 1$ & $0 \pm 0$ \\
Lavenders Lavandula spp. & $5 \pm 1$ & $0 \pm 0$ \\
Phillyrea angustifolia & $1 \pm 0$ & $0 \pm 0$ \\
Mastic Pistacia lentiscus & $5 \pm 1$ & $0 \pm 0$ \\
Myrtle Myrtus communis & $3 \pm 1$ & $1 \pm 0$ \\
Bramble Rubus ulmifolius & $1 \pm 0$ & $1 \pm 0$ \\
Lusitanian oak Quercus lusitanica & & \\
\hline
\end{tabular}

For cover estimation of tree species we considered the percentage of horizontal projection of their crowns; for shrubs we considered the percentage of ground covered 
Table 3 Vegetation features average and standard deviation according the two management types of cork oak Quercus suber woodlands: dense montados (DM) and sparse montados (SM). Degrees of freedom $(d f=1 ; 19), F$ test and associated probabilities. $D B H$ trunk diameter at breast high, $H^{\prime}$ Shannon diversity index

\begin{tabular}{lllllll}
\hline & DBH $(\mathrm{cm})$ & Foliage cover $(\%)$ & Oak cover $(\%)$ & Shrub cover $(\%)$ & Shrub diversity $\left(\mathrm{H}^{\prime}\right)$ & Tree diversity $\left(\mathrm{H}^{\prime}\right)$ \\
\hline DM $(n=20)$ & $25.5 \pm 5.8$ & $68 \pm 15$ & $60 \pm 14$ & $69 \pm 15$ & $1.91 \pm 0.43$ & $0.49 \pm 0.11$ \\
SM $(n=20)$ & $31.6 \pm 7.1$ & $69 \pm 15$ & $49 \pm 7$ & $18 \pm 4$ & $0.87 \pm 0.19$ & $0.04 \pm 0.01$ \\
$F$ test & 5.06 & 0.25 & 6.61 & 106.95 & 70.62 & 28.88 \\
$p$ & 0.030 & 0.618 & 0.014 & $<0.001$ & $<0.001$ & $<0.001$ \\
\hline
\end{tabular}

3.3 Effects of management type and vegetation features on leaf-chewing defoliators

The sawfly $P$. andrei caused the most important defoliation damage in both management systems (Table 5). Yet, the differences were more evident in SM, for which the impact by the sawfly was more than twice the impact caused by all moth defoliators. Furthermore, sawfly defoliation damage was significantly lower in DM than in SM. Yet similar damage intensities by moths were found in the two systems (Table 5). In general, Spearman's $r$ correlation coefficients between defoliators damage and vegetation features were lower than those of bird guilds. The negative relationship between sawfly damage and shrub cover was the only significant statistical correlation $\left(r_{\mathrm{s}}=-0.43, p<0.01\right)$.

\section{Discussion}

4.1 Relationships between management type and vegetation features

In the multifunctional montado system, the reduction of shrub cover and diversity can be a complex process from: clearing (for the improvement of the cork pruning activity and/or for pasture establishment) or overgrazing and the consequent soil erosion (Bugalho et al. 2009; Pinto-Correia and Mascarenhas 1999). In the study area, SM are managed in order to promote larger trees for cork production. Simultaneously, the improvement of pastures in the under-canopy layer promotes beef cattle production. Therefore, tree species with lower economical value were drifted to marginal lands (e.g. kermes oak
Quercus coccifera, Iberian pear Pyrus bourgaeana) and are therefore absent in SM. The remaining shrub community is dominated by unpalatable (e.g. gorses and daphne) and pioneer shrubs (gum rockrose Cistus ladanifer; e.g. Correia 2002). On the other hand, the vegetation density and diversity detected in DM can have two different origins: relict forest with purely cork-pruning management or as a result of reforestation actions. Cork oak reforestation in DM does not explain the higher diversity of other woody plant species by itself, but instead allows their maintenance by the reduction of cattle impact in reforested plots. Thus DM contributes in part to the conservation of some plant species representative of the ancient forest type (e.g. kermes oak).

\subsection{Effects of management type and vegetation features on insectivorous birds}

Significant variations in insectivorous bird densities were obtained according to the intensity of management system conducted in montados. This result is consistent with that obtained by Godinho and Rabaça (2011), where variables associated with management activities better explained the variation in bird communities in Portuguese cork oak montados. However, not all studied bird guilds decreased their densities with the increase of management intensity. Moreover, only lower strata bird guilds differed between both systems: ground-bird densities were higher in SM while shrub-birds and leaf-warbler densities were lower in the same system. In holm oak forests in Catalonia, Camprodon and Brotons (2006) found negative thinning effects on shrub-birds abundances and richness but positive in some tree dwelling species. However, the high densities

Table 4 Density of bird guilds (averages and standard deviation) expressed in number of pairs/3 ha according the two management types of cork oak Quercus suber woodlands: dense montados (DM) and sparse montados (SM)

\begin{tabular}{lllllll}
\hline & Finches & Climbing birds & Tits & Ground birds & Shrub birds & Leaf warblers \\
\hline DM $(n=20)$ & $1.8 \pm 0.4$ & $0.5 \pm 0.1$ & $0.8 \pm 0.2$ & $1.4 \pm 0.3$ & $2.4 \pm 0.5$ & $1.1 \pm 0.3$ \\
SM $(n=20)$ & $2.1 \pm 0.5$ & $0.7 \pm 0.2$ & $0.8 \pm 0.2$ & $2.4 \pm 0.5$ & $0.6 \pm 0.1$ & $0.3 \pm 0.1$ \\
$F$ test & 0.88 & 0.58 & 0 & 4.68 & 0.037 & $<.87$ \\
$p$ & 0.354 & 0.450 & 1 & $<0.001$ & 12.64 \\
\hline
\end{tabular}

Degrees of freedom $(d f=1 ; 19), F$ test and associated probabilities 
Table 5 Average percentage and standard deviation of oak leaves affected by each defoliator group (within a $1 \mathrm{~m}^{2}$ of crown) according the two management types of cork oak Quercus suber woodlands: dense montados (DM) and sparse montados (SM)

\begin{tabular}{lll}
\hline & Moth defoliation & Sawfly defoliation \\
\hline $\mathrm{DM}(n=20)$ & $12.1 \pm 2.7$ & $16.9 \pm 3.8$ \\
$\mathrm{SM}(n=20)$ & $11.3 \pm 2.5$ & $24.0 \pm 5.4$ \\
$F$ test & 0.16 & 6.23 \\
$p$ & 0.696 & 0.017 \\
\hline
\end{tabular}

Degrees of freedom $(d f=1 ; 19), F$ test and associated probabilities

of chaffinch Fringilla coelebs in the study area (the commonest among studied bird species and the unique species within finches' guild) may have compromised the achievement of significant differences between the studied management systems. On the other hand, since the average trunk diameters were large enough to hold suitable size cavities for nesting in both systems, this was not a limiting factor for hole nesters (climbing-birds and tits). As an example, Strubbe and Matthysen (2009) found that in Belgium parks, nuthatch Sitta europaea selected holes in trees with about $25 \mathrm{~cm}$ DBH. Despite differences in tree species between Belgium and our study area, such diameter was roughly similar to the lower trunk average diameters recorded in DM systems.

Regarding the relations of birds with vegetation features, our results indicate that the densities in the tits guild can be affected by foliage density. Despite tits are known predators of oak defoliators and play an important role on their control (e.g. Murakami and Nakano 2000; Sanz 2001), our data does not allow us to evaluate such relation due to several unstudied factors like interspecific competition, larvae availability and bird food requirements. We expect that a sparse crown with great sun exposition should be preferentially selected by foraging birds due to a higher success in prey detection or predator avoidance. Carrascal and Alonso (2006) using artificial feeders to test the vigilance activity of tits and nuthatches pointed to a similar direction. Therefore, since foliage density was rather similar in both management systems (see Table 3), the tits' densities did not differ (see Table 4). Considering the synchronization between tree foliage phenology, the development of arboreal caterpillars and the breeding season of tits (Kalapanida and Petrakis 2012; Sanz 2001; Southwood et al. 2004), we admit that tits can be attracted to trees with reduced foliage density looking for prey larvae in buds or twigs instead in leaves. However, most of the bird guilds affected by vegetation traits presented none or reduced dependence on oak trees for foraging and nesting: ground birds, shrub birds and leaf warblers. Contrarily to farmland habitats where ground-birds decrease with the intensification of system (Bengtsson et al. 2005;
BirdLife International 2004; Butler et al. 2010), in montados their densities increased from DM to SM. The species composition of the ground-birds guild depends on the existence of mosaic habitats with high herbaceous cover and tolerance to the presence of some woody vegetation (e.g. Godinho and Rabaça 2011). Furthermore, Pulido and Díaz (1992) found a higher proportion of ground foragers in grazed dehesas than in shrubby plots. Actually, a sparse montado landscape shows traits favouring ground-birds, such as large areas of herbaceous cover (fan-tailed warbler Cisticola juncidis), fragmented cover of woody-vegetation (corn bunting Emberiza calandra and stonechat Saxicola torquata), fragmented treelayer (woodlark Lullula arborea) and strong agro-forest edge effects (cirl bunting Emberiza cirlus). On the other hand, habitat features in SM promote lower densities of shrub birds and leaf warblers. Despite some differences in their foraging and nesting habits (leaf warblers seldom use ground level and shrub birds rarely use tree layer), bird relationships with vegetation features were rather similar. Similarly to our results and based more on thinning effects than on vegetation diversity reduction, Camprodon and Brotons (2006) detected a significant association with the abundance of shrub birds and management activities. They found that undergrowth clearing brought a significant simplification in the vertical structure of the forest, which probably reduced foraging opportunities and breeding resources for most shrub dwelling species. These effects became more pronounced when tree thinning was applied together with undergrowth clearing. However, authors detected no effects on Bonelli's warbler Phylloscopus bonelli abundances (a leaf warbler species). Those results were related to a higher dependence of shrub birds on micro-climatic conditions (exception for the generalist Sardinian warbler Sylvia melanocephala) whereas leafwarblers should be dependent on vegetation species. In our study, leaf-warblers selected non-pure montados, preferring mixed forest habitats with pines (Bonelli's warbler) or bordered by deciduous-trees (melodious warbler Hippolais polyglotta). On the other hand, nightingale Luscinia megarhynchos and wren Troglodytes troglodytes prefer tall, dense, wet and shaded shrubby cover, which is more similar to an understory structure often common in DM. Moreover, in Mediterranean climate areas of southern Portugal those species are more frequent in well vegetated riparian galleries than in the woodland matrix (see for instance Godinho and Rabaça 2011). The Sardinian warbler is a shrub-bird with broad habitat preferences, but playing an important role in montados diversification through seed dispersal during fruit ripening season (Herrera 1984). In our study, this resident and highly site-fidelity throughout the year species was rare in SM (1) due to lack of adequate breeding habitat and (2) eventually because fleshy fruit plants (e.g. myrtle Myrtus communis, Phillyrea angustifolia and bramble Rubus ulmifolius) were rare or absent (see Table 2). 
4.3 Effects of management type and vegetation features on leaf-chewing defoliators

The studied leaf-chewing defoliator groups presented different levels of complexity in their taxonomic identity. Sawflies are represented by one unique species, $P$. andrei, which frequently occurs in the cork oak forest in Portugal, whereas the moths group is composed of many species from several families (Ferreira and Ferreira 1991). For example, for Italy 52 moth species are described as affecting cork oak foliage (Luciano and Roversi 2001), the majority belonging to the same families we found in the studied sites. In both management systems the main defoliation was caused by the sawfly $P$. andrei. These high proportions of sawfly incidence are contrary to other studies scoped in leafchewers communities of oaks in Europe (Kalapanida and Petrakus 2012; Skuhravý et al. 1998), North America (Forker et al. 2004; Marquis and Whelan 1994) and Japan (Murakami and Nakano 2000) for which Lepidoptera are dominant defoliators. Also, sawfly damage does not seem to be relevant in cork oak forest from other Mediterranean regions, both in South Europe and North Africa, as revised by Branco and Ramos (2009). P. andrei is an oak specialist, highly prevalent in the studied area, exhibiting outbreak dynamics since the sixties of the last century (Baeta-Neves et al. 1972). Since oligotrophic species are benefited by the concentration of the main host species rather than generalists (see for instance Jactel and Brockerho 2007), the dominance of oaks in selected sites (more than $80 \%$ of tree composition) probably account for the recorded high densities of this sawfly. This fact was even more evident in SM, where woody vegetation composition can be roughly compared to an oak monoculture (Table 2).

The two management types differed significantly on the damage caused by sawflies but not by moths. Sawfly defoliation was higher at SM, where it was apparently benefited by the fragmented shrub cover. Consistently, a negative relationship between sawfly damage and shrub cover was observed. $P$. andrei pupates in the soil, goes through a nine 10-month diapause, completing one generation per year, but some individuals exhibit prolonged diapause up to 3 years (Ferreira and Ferreira 1991). Higher success of their development and survival is expected in more sunny areas with lower woody vegetation cover, due to more suitable climatic conditions, as observed in other defoliators pupating in the soil (Dulaurent et al. 2011). Moreover, in general lower rates of defoliator parasitism are often found in fragmented habitats compared with continuous forests, probably due to unsuitable microclimatic conditions for their development (Roland et al. 1997). Thus, we hypothesize that historic management practices on SM might have allowed the maintenance of higher levels of sawflies, by reducing vegetation density and its consequent effect on parasitism levels, with a significant contribution to their current densities. Accordingly, Rubtsov (1996) highlighted the importance of consecutive defoliations in the reduction of timber production in Russian oaks. Similarly, taking into account the economic valuation of cork, the effects of consecutive sawfly defoliations in cork oak growth must be urgently evaluated.

Since moth species differ on their ecological niches, the influence of the vegetation traits might have disparities among species, thus jeopardizing the differences obtained for average defoliation rates between the two management systems. Effectively, the moth group includes many micro-habitat specialists, such as those that drop eggs only on trunks free from shrub encroachment, and many trophic generalists that consume many other woody plants beyond oak leafs with varying host ranges (Ferreira and Ferreira 1991; Luciano and Roversi 2001). Some moth species can be dependent on shrub vegetation, using alternative host species in these vegetation layers.

Our results are based on an evaluation of the percentage of leaves with signs of defoliation as an indicative measure of defoliators. If we had used more accurate estimates, as the biomass loss at each leaf level, we would have probably obtained (1) even higher differences in sawfly densities; and (2) some differences between moth densities between the two management systems.

\subsection{Conclusions}

We found that insectivorous birds and defoliator insects were significantly affected by the type of management in the montado system: shrub-birds and leaf-warblers decreased with the increase of management intensity whereas ground-birds and sawfly damage exhibited an opposite trend. Our results highlight the relevance of activities conducted at under-canopy layer (e.g. shrub clearing, crop growing or grazing) for animal communities in montados. Moreover, actions conducted at the tree level can result in further consequences: in studied management systems the increase of tree diversity can (1) benefit leafwarbler densities and (2) might help maintaining sawfly attack at lower levels, improving the ecosystem equilibrium. Accordingly, future work focused in the sawfly defoliation influence in cork production should be conducted. Concluding, the increase of tree diversity can improve the habitat suitability for leaf-warblers like Bonelli's warbler-a species with an unfavourable trend with populations concentrated in Europe (BirdLife International 2004). Moreover, mixed stands with cork oaks and pines may give additional incomes for landowners (e.g. pine timber and resin), and a mosaic landscape with different woody vegetation densities and diversities can endorse a rich bird community and eventually reduce the defoliator impact. Taking into account the generalized trend of forest abandonment across the Mediterranean, a sustainable multifunctional system can have an important role in conserving the natural resources of the region. 
Acknowledgments We are grateful to Eng. Rui Alves (Forestry and Natural Resources Department, Companhia das Lezírias S.A.) for all logistic support. We appreciated the comments and suggestions of fellow researchers, which helped to improve the scientific value of the study: Rita Azedo, Sara Santos, Pedro Salgueiro and Rui Lourenço. The authors are thankful to two anonymous referees for their valuable comments and suggestions to an earlier version of the manuscript.

Funding This study was totally funded by Companhia das Lezírias S.A. under the European Business and Biodiversity initiative (project designation: CL/UE-B\&B2008/12 - Biodiversity Valorisation of Companhia das Lezírias).

\section{References}

Baeta-Neves CML, Cabral MTC, Nogueira CDS, Ferreira LJC (1972) Bio-ecologia da Tortrix viridana L. e combate da Lymantria dispar L. pela luta biológica, Instituto Superior de Agronomia, Lisboa

Barriga JC, Lassaletta L, Moreno AG (2010) Ground-living spider assemblages from Mediterranean habitats under different management conditions. J Arachnol 38:258-269

Bengtsson J, Ahnstrom J, Weibull AC (2005) The effects of organic agriculture on biodiversity and abundance: a meta-analysis. J Appl Ecol 42:261-69

Bibby CJ, Burgess ND, Hill DA, Mustoe S (2000) Bird census techniques, 2nd edn. Academic, London

BirdLife International (2004) Birds in the European Union: a status assessment. Wageningen, BirdLife International, The Netherlands

Branco M, Ramos AP (2009) Coping with pests and diseases. In: Aronson J, Pereira JS, Pausas JG (eds) Cork Oak Woodlands: ecology, adaptive management, and restoration of an Ancient Mediterranean ecosystem. Island Press, Washington (DC), pp 103-111

Bugalho M, Plieninger T, Aronson J, Ellatifi H, Crespo DG (2009) Open woodlands: A diversity of uses (and overuses). In: Aronson J, Pereira JS, Pausas JG (eds) Cork Oak Woodlands: ecology, adaptive management, and restoration of an Ancient Mediterranean ecosystem. Island Press, Washington (DC), pp 33-45

Bugalho MN, Lecomte X, Gonçalves M, Caldeira MC, Branco M (2011) Establishing grazing and grazing-excluded patches increases plant and invertebrate diversity in a Mediterranean oak woodland. Forest Ecol Manag 261:2133-2139

Butler SJ, Boccaccio L, Gregory RD, Vorisek P, Norris K (2010) Quantifying the impact of land-use change to European farmland bird populations. Agric Ecosyst Environ 137:348-357

Camprodon J, Brotons L (2006) Effects of undergrowth clearing on the bird communities of the Northwestern Mediterranean Coppice Holm oak forests. Forest Ecol Manag 221:72-82

Carrascal LM, Alonso CL (2006) Habitat use under latent predation risk. A case study with wintering forest birds. Oikos 112:51-62

Correia OA (2002) Os cistus: As especies do futuro? In: Loução MA (ed) Fragmentos de ecologia. Escolar Editora, Lisboa, pp 97-119

Costa A, Madeira M, Oliveira AC (2008) The relationship between cork oak growth patterns and soil, slope and drainage in a cork oak woodland in Southern Portugal. Forest Ecol Manag 255:1525-1535

Dulaurent AM, Porté AJ, van Halder I, Vétillard F, Menassieu P, Jactel $\mathrm{H}$ (2011) A case of habitat complementation in forest pests: pine processionary moth pupae survive better in open areas. Forest Ecol Manag 261:1069-1076

Ferreira MC, Ferreira GWS (1991) Pragas das folhosas. Guia de campo n. ${ }^{\circ}$ 4, DGPA, Lisboa

Forker RE, Marquis RJ, Lill JT (2004) Feeny revisited: condensed tannins as antiherbivore defences in leaf-chewing herbivore communities of Quercus. Ecol Entomol 29:174-187
Godinho C, Rabaça JE (2011) Birds like it corky: the influence of habitat features and management of 'montados' in breeding bird communities. Agroforest Syst 82:183-195

Herrera CM (1984) A study of avian frugivores, bird-dispersed plants, and their interaction in Mediterranean scrublands. Ecol Monogr $54: 1-23$

SPSS Inc, 2007. SPSS 16.0 for Windows, Chicago, IL

Jactel H, Brockerho VEG (2007) Tree diversity reduces herbivory by forest insects. Ecol Lett 10:835-848

Kalapanida M, Petrakis P (2012) Temporal partitioning in an assemblage of insect defoliators feeding on oak on a Mediterranean mountain. Eur J Entomol 109:55-69

Leiva MJ, Fernández-Alés R (2005) Holm-oak (Quercus ilex subs. ballota) acorns infestation by insects in Mediterranean dehesas and shrublands. Its effect on acorn germination and seedling emergence. Forest Ecol Manag 212:221-229

Luciano P, Roversi PF (2001) Oak defoliators in Italy. Edizioni Poddighe Sassari, Sassari

Marañon T (1986) Plant species richness and canopy effect in the savanna like 'dehesa' of S.W. Spain. Ecol Mediterr 12:131-141

Marquis RJ, Whelan CJ (1994) Insectivorous birds increase growth of white oak through consumption of leaf-chewing insects. Ecol 75:2007-2014

Martins da Silva P, Aguiar CAS, Niemelä J, Sousa JP, Serrano ARM (2008) Diversity patterns of ground beetles (Coleoptera: Carabidae) along a gradient of land-use disturbance. Agric Ecosyst Environ 124:270-274

Murakami M, Nakano S (2000) Species-specific bird functions in a forest-canopy food web. Proc R Soc London B 267:1597-1601

Pinto-Correia T, Mascarenhas J (1999) Contribution to the extensification/intensification debate: new trends in the Portuguese montado. Landsc Urban Plan 46:125-131

Pulido FJ, Díaz M (1992) Relaciones entre la estructura de la vegetación y las comunidades de aves nidificantes en las dehesas: influencia del manejo humano. Ardeola 39:63-72

Roland J, Taylor P, Cooke B (1997) Forest structure and the spatial pattern of parasitoid attack. In: Watt AD, Stork NE, Hunter MD (eds) Forests and insects. Chapman \& Hall, London, pp 97-106

Rubtsov VV (1996) Influence of repeated defoliations by insects on wood increment in common oak (Quercus robur L.). Ann For Sci 53:407412

Sanz JJ (2001) Experimentally increased insectivorous bird density results in a reduction of caterpillar density and leaf damage to Pyrenean oak. Ecol Res 16:387-394

Scarascia-Mugnozza G, Oswald H, Piussi P, Radoglou K (2000) Forests of the Mediterranean region: gaps in knowledge and research needs. Forest Ecol Manag 132:97-109

Skuhravý V, Hrubík P, Skuhravá M, Pożgaj J (1998) Occurrence of insects associated with nine Quercus species (Fagaceae) in cultured plantations in southern Slovakia during 1987-1992. J Appl Entomol 122:149-155

Smit C, Díaz M, Jansen P (2009) Establishment limitation of holm oak (Quercus ilex subsp. ballota (Desf.) Samp.) in a Mediterranean savanna - forest ecosystem. Ann For Sci 66:511-517

Smith DR (2006) List of the sawflies (Hymenoptera: Symphyta) of Virginia. Banisteria 28:3-23

Snow DW, Perrins CM (1998) The birds of the Western Palearctic. Concise edition, vol 1-2. Oxford University Press, Oxford

Southwood TRE, Wint GRW, Kennedy CEJ, Greenwood SR (2004) Seasonality, abundance, species richness and specificity of the phytophagous guild of insects on oak (Quercus) canopies. Eur J Entomol 101:43-50

Strubbe D, Matthysen E (2009) Experimental evidence for nest-site competition between invasive Ring-necked Parakeets (Psittacula krameri) and native Nuthatches (Sitta europaea). Biol Conserv 142:1588-1594

Tellería JL (2001) Passerine bird communities of Iberian dehesas: a review. Anim Biodivers Conserv 24:67-78 